\title{
Resource use efficiency of maize production in Jammu Region of J \& K State
}

\author{
Arti Sharma ${ }^{1}$, Jyoti Kachroo², Anil Bhat ${ }^{2}$, Dileep Kachroo ${ }^{3}$ and Quadri Javeed Ahmad \\ Peer $^{4 *}$
}

${ }^{1}$ Division of Agricultural Economics and ABM, Sher-e-Kashmir University of Agricultural Sciences and Technology of Jammu, Jammu (J\&K), INDIA

${ }^{2}$ Division of Agricultural Economics and ABM, Sher-e-Kashmir University of Agricultural Sciences and Technology of Jammu, Jammu (J\&K), INDIA

${ }^{3}$ Division of Agronomy, Sher-e-Kashmir University of Agricultural Sciences and Technology of Jammu, Jammu (J\&K), INDIA

${ }^{4}$ Division of Agricultural Statistics, Economics and Extension, FOA, Wadura, Sher-e-Kashmir University of Agricultural Sciences and Technology of Kashmir, INDIA

*Corresponding author. E-mail: qadrijavid2008@gmail.com

Received: August 24, 2014; Revised received: February 8, 2016; Accepted: April 30, 2016

\begin{abstract}
Maize one of the important crops of rainfed agriculture is grown in low, mid and high hill altitudes. The study was conducted on resource use efficiency of maize production in Jammu Region of J\&K state during the year 2007-08. Jammu region of state observed a positive trend for area but negative for yield of maize. In sampled districts, area under maize cultivation contributed positively in production but yield and interaction effect of both factors contributed negatively during the overall period of twenty years. The allocative efficiency was $0.014,0.668$, $1.019,3.244$ and 13.38 respectively for labour, capital, irrigation and fertilizers ( $\mathrm{N}$ and $\mathrm{K}$ ), respectively and the allocative efficiency of fertilizer $(P)$ was negative $(-1.732)$. Maximum likelihood estimates showed that the value of variance parameters lambda $(\lambda)$ was 4.219 and that of sigma $(\sigma)$ was 0.455 , which were significantly different from zero indicating a good fit and the correctness of the distributional assumptions specified and the value of gamma $(Y)$ was 0.946 indicating 94 per cent of variation between the observed output and frontier output The estimated elasticities of the explanatory variables like labour $(0.378)$, capital $(0.336)$, irrigation $(0.225)$, nitrogen $(0.244)$ and potash $(0.292)$ were positive while the value of phosphate $(-0.383)$ was negative. The analysis of results showed that the returns to scale (RTS) was 1.092. Factors that affected on technical efficiency predicted the regression coefficient for education as 0.023 and farm size as 0.878 and for the proportion of female workers $(0.062)$ in the family was also positively significant.
\end{abstract}

Keywords: Allocative efficiency, Growth analysis, Growth trend, Maize, Technical efficiency

\section{INTRODUCTION}

Maize, globally the top ranking cereal is a potential crop in productivity and production. Due to its higher productivity and applicability, the culture of maize spread rapidly around the globe and currently is being produced in more than 100 countries of the world. America is the highest producer of maize with 42.28 per cent production out of the total world's maize production. In India, maize is emerging as the third most important crop after rice and wheat and ranks fifth in the world in terms of area $(7.77$ million hectare) and tenth in production (14.71 million tones), but occupies fifteenth place in terms of productivity, which accounts to 1.78 tones/ ha (Anonymous, 2008). Maize has got more than 3500 value added products of daily application and 50 per cent of its produce is being used as animal feed, (Singh et al., 2003), which enhances its marketability and price and is having a promising option for diversifying agriculture in hilly ecosystem of India.

The technology mission on maize in May, 1995 known as "Accelerated Maize Development Programme (AMDP)" was also included as component of "Integrated Cereals Development Programme (ICDP) and coarse cereals (CC) based cropping systems due to its magnitude of usage as human, animal food and poultry feed. Though it is a boon for a country like India because it contributes significantly to India's GDP (Rs.60 billion annually) and generates huge employment i.e., 450 million man-days (Singh et al., 2003), yet there is a need to pragmatise its strategies for improvement in terms of production, productivity and marketability to bring it at par with world productivity of 4.97 tones/ ha

The state of Jammu and Kashmir one of the 26 states (with VIII $^{\text {th }}$ rank in the production) which have come under technology mission on maize is potential maize growing state, accounting for 4.11 per cent $(0.32 \mathrm{mha})$ 
and 3.26 per cent $(0.48 \mathrm{mt})$ of the total national maize area and production with average yield of $1.50 \mathrm{t} / \mathrm{ha}$ (Anonymous, 2008). As far as Jammu region of J \& K state is concerned, it is a prominent crop and covers about $0.21 \mathrm{mha}$ land, with $0.38 \mathrm{mt}$ of production and $1.73 \mathrm{t} /$ ha productivity, which is marginally lower than the national average of $1.78 \mathrm{t} / \mathrm{ha}$, whereas the six major maize growing districts of Jammu region out of ten districts (Jammu, Kathua, Udhampur, Rajouri, Poonch and Doda) have yield of more than national average $(2.14 \mathrm{t} / \mathrm{ha})$. Inspite of more yield of these districts in comparison to national level, yet the yield differences between research farms (3.7 t/ha) and farmers field $(2.1 \mathrm{t} / \mathrm{ha})$ was realized to be $1.6 \mathrm{t} / \mathrm{ha}$ and between demonstration field (3.4 t/ha) and farmers field (2.1 tonnes/ha) was found to be $1.3 \mathrm{t} / \mathrm{ha}$, which indicates that the existing potential is yet to be realized. Available evidences in the last few years revealed that technological package via efficient utilization of scarce resources may accelerate the pace of its production. It is therefore, necessary to quantify current levels of technical efficiency so as to estimate losses in production that could be attributed to inefficiencies due to differences in socio-economic characteristics and management practices. A detailed examination of the farm efficiency in terms of technical, allocative and economic for increasing productivity in a state like Jammu and Kashmir is equally important. Before, working out all the three efficiencies, it becomes imperative to analyse the status of maize in Jammu and Kashmir. The present study examines various aspects of economic efficiency of maize production in Jammu region of Jammu and Kashmir state so that suitable policy option for enhancing maize production and productivity can be implicated.

\section{MATERIALS AND METHODS}

The research was confined to hilly tracts of Doda and Udhampur districts of Jammu region. Three blocks from each district as secondary stage units, then two villages from each block as the third stage units and ultimately twenty households from each village so as to constitute sample size of 240 households were randomly selected.

Status of maize: In order to study the status of maize, the present study made use of time-series data on different variables like area, production and yield of maize for Jammu \& Kashmir State, Jammu region and for selected districts separately. For working out the growth rates of area, production and yield of maize crop for the period of twenty years, the data was divided into three different periods as:

(I) Period I (1987-88 to 1996-97)

(II) Period II (1997-98 to 2006-07) and

(III) Overall Period (1987-88 to 2006-07)

In order to work out the trend of variables like area, production and yield, compound growth rate as used by Kachroo and Kachroo (2006) were calculated as follows: $\mathrm{yt}=\mathrm{ab}^{\mathrm{t}}$

Then, compound growth rate $(r)=(b-1) * 100$ was estimated with the help of computing package SPSS, 7.5. version.

The growth rates were tested statistically for their significance through $\mathrm{t}-$ test as given below :

$\mathrm{t}=\mathrm{r} /$ S.E. $(\mathrm{r}) \sim \mathrm{t}_{\alpha, \mathrm{n}-2}$

Decomposition of growth analysis: For analyzing effect of area, productivity and their interaction in increasing the maize production was examined by using differential equation as used by Kachroo and Sharma (2008).

$\Delta \mathrm{P}=\mathrm{Y}_{0} \Delta \mathrm{A}+\mathrm{A}_{0} \Delta \mathrm{Y}+\Delta \mathrm{A} \Delta \mathrm{Y}$

Where, $\Delta A=A_{n}-A_{0}, \Delta Y=Y_{n}-Y_{0}, \Delta P=P_{n}-P_{0}$ and $A_{0}$, $\mathrm{Y}_{0}, \mathrm{P}_{0}$ were the area, yield and production, respectively in base year, whereas $A_{n}, Y_{n}$ and $P_{n}$ were area, yield and production in current year, respectively and $\Delta \mathrm{A}$, $\Delta \mathrm{Y}, \Delta \mathrm{P}$ were the changes in area, yield and production, respectively. Thus, the changes in production $(\Delta \mathrm{P})$ were due to:

(i) Area effect $\left(\mathrm{Y}_{0 .} \Delta \mathrm{A}\right)$ (ii) Yield effect $\left(\mathrm{A}_{0 .} \Delta \mathrm{Y}\right)$

(iii) Interaction of area and yield effect $(\Delta \mathrm{A} . \Delta \mathrm{Y})$

Measurement of resource use efficiency: It is a key factor for increasing productivity. Technical and allocative efficiencies were employed to measure the resource use efficiency. The technical efficiency in production was estimated by using the stochastic frontier production function. The regression co-efficient of factor input from Cobb-Douglas production function (OLS) were used to calculate the Marginal Value Production (MVP) at Geometric mean level for the average farms. In order to study resource - allocative efficiency, the ratio of MVP of a respective input to the marginal factor cost (MFC) for each input was compared and tested for its equality to 1, i.e. $\mathrm{MVP} / \mathrm{MFC}=1$ (Yotopoulos, 1967) .

To calculate Marginal Value Productivity (MVP) of resource $\mathrm{x}_{\mathrm{i}}$, the following formula had been used.

$$
\mathrm{MVP}=\frac{\mathrm{b}_{\mathrm{i}}[\mathrm{GM}(\mathrm{Y})}{\left.\mathrm{GM}\left(\mathrm{X}_{\mathrm{i}}\right)\right]}
$$

Where MVP $\left(\mathrm{x}_{\mathrm{i}}\right)$ is the Marginal Value Productivity of ith resource:

$\mathrm{b}_{\mathrm{i}}$ is the regression coefficient

GM (Y) is the Geometric Mean of output

$\mathrm{GM}\left(\mathrm{X}_{\mathrm{i}}\right)$ is the Geometric Mean of inputs

Stochastic production frontier and technical efficiency: The stochastic frontier production function was independently proposed by Aigner et al. (1977), Meeusen and Van den Broeck (1977). This function is defined by;

$\mathrm{Y}_{\mathrm{i}}=\mathrm{f}\left(\mathrm{x}_{\mathrm{i}} ; ß\right)+\mathrm{e}_{\mathrm{i}}$

Where, $\mathrm{i}=1,2, \ldots, \mathrm{N}$

$\mathrm{e}_{\mathrm{i}}=\mathrm{v}_{\mathrm{i}}-\mathrm{u}_{\mathrm{i}}$

Technical inefficiency is therefore defined as the amount by which the level of production for the farm is less than the frontier output.

$\mathrm{TE}_{\mathrm{i}}{ }^{\wedge}=\mathrm{Y}_{\mathrm{i}} / \mathrm{Y}_{\mathrm{i}}{ }^{*}$, where $\mathrm{Y}_{\mathrm{i}}{ }^{*}=\mathrm{f}\left(\mathrm{x}_{\mathrm{i}} ; \beta\right)$, highest predicted value for the ith farm 
$\mathrm{TE}_{\mathrm{i}}{ }^{\wedge}=\operatorname{Exp}\left(-\mathrm{u}_{\mathrm{i}}\right)$

Technical inefficiency $=1-\mathrm{TE}^{\wedge}{ }_{\mathrm{i}}$

The maximum likelihood estimates (MLE) of the parameters of the model defined by equation

$Y=f\left(X_{i} \beta\right) \exp \left(V_{i}-U_{i}\right)$.

Where $Y_{i}=$ is the production of the $i^{\text {th }}$ farm $(i=1,2,3$ ----n), $\mathrm{Xi}$ is a (1x k) vector of functions of input quantities applied by the $i^{\text {th }}$ farm; $\beta$ is a $(1 \mathrm{x} \mathrm{k})$ vector of unknown parameters to be estimated. $\mathrm{V}_{\mathrm{i}}^{\mathrm{s}}$ is random variables assumed to be independent.

Specification of the model: The stochastic frontier production function of the Cobb-Douglas type was specified for the present study and estimated by using Limdep computing package. The model used as:

In $\mathrm{y}_{\mathrm{i}}=\beta_{\mathrm{i} 0}+\beta_{\mathrm{i} 1}$ In $\mathrm{L}+\beta_{\mathrm{i} 2}$ In $\mathrm{F}+\beta_{\mathrm{i} 3}$ In $\mathrm{K}+\beta_{\mathrm{i} 4}$ In $\mathrm{I}+\mathrm{v}_{\mathrm{i}}{ }^{-}$ $\mathrm{u}_{\mathrm{i}} \quad(\mathrm{i}=1,2, \ldots \ldots, \mathrm{n})$

Where,

$\mathrm{Y}_{\mathrm{i}}=$ Yield of maize in the ith farm $(\mathrm{q} / \mathrm{ha})$

$\mathrm{L}=$ Human labour used in maize crop (mandays/ ha)

$\mathrm{F}=$ Quantity of fertilizer $(\mathrm{N}+\mathrm{P}+\mathrm{K})$ used $(\mathrm{kg} / \mathrm{ha})$ in maize crop

$\mathrm{K}=$ Capital which included overhead expenditure on animal and machine labour and seeds (Rs/ha)

$\mathrm{I}=$ Irrigation no. of times applied

$\mathrm{V}_{\mathrm{i}}-\mathrm{u}_{\mathrm{i}}=$ Random error-term

The following linear regression model was used to identify the socio-economic factors that condition technical efficiency of sample farms.

$\mathrm{L}_{\mathrm{n}}[\mathrm{TE} /(1-\mathrm{TE})]=\beta_{0}+\beta_{1} \mathrm{X}_{1 \mathrm{ij}}+\beta_{2} \mathrm{X}_{2 \mathrm{ij}}+\beta_{3} \mathrm{X}_{3 \mathrm{ij}}+\beta_{4} \mathrm{X}_{4 \mathrm{ij}}$ $+\beta_{5} \mathrm{X}_{5 \mathrm{ij}}+\mathrm{u}_{\mathrm{i}}$

Where,

$\mathrm{TE}_{\mathrm{ij}}=$ Technical efficiency for ith crop on $\mathrm{j}$-th farm,

$\beta_{0}=$ Intercept $/$ Constant

$\beta_{\mathrm{i}}=$ regression coefficients,

$\mathrm{X}_{1}=$ age of the head of family

$\mathrm{X}_{2}=$ proportion of female workers in total agricultural workers in the family,

$\mathrm{X}_{3}=$ proportion of children in the family as helper,

$\mathrm{X}_{4}=$ dummy for adult members/ having education above primary level,

$\mathrm{X}_{5}=$ farm size and $\mathrm{u}_{\mathrm{i}}=$ error term.

\section{RESULTS AND DISCUSSION}

Production status of maize: The compound growth rates for area, production and yield of maize in Jammu and Kashmir State indicated that maize recorded a significant growth rate during the overall period of twenty years as shown in Table1., whereas, the maize production and yield decelerated heavily during the period II. The Table 2 showed that the compound growth rates for area and production in Jammu region of J\&K State during the overall period showed positively significant growth rates but negatively significant in yield. Decline in production can be attributed to a decline in yield, although the area had increased.

Similarly, the growth performance of maize area, production and yield in sample districts of Jammu region as shown in Table 3 and Table 4, indicated that the growth rates for production and yield of maize crop in Doda and Udhampur district was not impressive during overall period. However, the growth trend of area was positive and significant in these two districts. Awasthi (2003) expressed similar views in his study on maize production in Madhya Pradesh, while taking a district level analysis The limiting factors for maize farming were found to labour problems, erratic rainfall, poor genotypes, incidences of diseases, lack of transportation facilities and low market price in selected districts of J\&K State.

Decomposition of maize production into area, yield and their interactional effects: The data regarding effect of change in area, yield and their interaction (Table 5) on the change in production of maize crop between the two periods for India (1987-88 to 1996-97 and 1997-98 to 2006-07), indicated that during period I, the change in area brought about a change in production by 0.714 million tonnes while keeping the productivity constant. Similarly, a change in yield changed the production by 3.892 million tonnes keeping area constant and the interaction effect of area and yield was 2.778 million tonnes on production during the period I. During period II, the change in area and yield brought about a change in production by 2.470 million tonnes and 0.442 million tonnes, respectively. The interaction effect of area and yield was 1.091 million tonnes on production during the period II. But the overall effect of two periods on production was 2.225

Table 1. Growth trend of area, production and yield of maize crop in India.

\begin{tabular}{lllll}
\hline S. N. & Particulars & Period I (1987-88 to1996-97) & Period II (1997-98 to 2006-07) & Overall period (1987-88 to 2006-07) \\
\hline 1. & Area & $0.859 *(0.002)$ & $2.658^{*}(0.002)$ & $0.870 *(0.001)$ \\
2. & Production & $3.637 *(0.015)$ & $3.806 *(0.007)$ & $3.132 *(0.002)$ \\
3. & Yield & $3.531 *(0.012)$ & $0.838^{*}(0.006)$ & $2.299 *(0.001)$ \\
\hline
\end{tabular}

*1 per cent level of significance. Figures in the parentheses denote standard errors of their respective coefficients

Table 2. Growth trend of area, production and yield of maize crop in Jammu and Kashmir state.

\begin{tabular}{lllll}
\hline S.N. & Particulars & Period I (1987-88 to1996-97) & Period II (1997-98 to 2006-07) & Overall period (1987-88 to 2006-07) \\
\hline 1 & Area & $0.441^{*}(0.001)$ & $0.350^{*}(0.002)$ & $0.701^{*}(0.008)$ \\
2 & Production & $3.620^{*}(0.161)$ & $(-) 0.070^{*}(0.090)$ & $0.952^{*}(0.004)$ \\
3 & Yield & $3.191^{*}(0.162)$ & $(-) 0.419^{*}(0.09)$ & $0.252^{*}(0.005)$ \\
\hline
\end{tabular}

*1 per cent level of significance. Figures in the parentheses denote standard errors of their respective coefficients 
Table 3. Growth trend of area, production and yield in Jammu region of $\mathrm{J} \& \mathrm{~K}$ state.

\begin{tabular}{lllll}
\hline S. N. & Particulars & Period I (1987-88 to 1996-97) & Period II (1997-98 to 2006-07) & Overall period (1987-88 to 2006-07) \\
\hline 1 & Area & $0.633^{*}(0.001)$ & $0.269^{*}(0.001)$ & $0.800^{*}(0.007)$ \\
2 & Production & $2.511^{*}(0.010)$ & $(-) 1.224^{*}(0.001)$ & $0.351^{*}(0.003)$ \\
3 & Yield & $0.155^{*}(0.012)$ & $(-) 1.496^{*}(0.009)$ & $(-) 0.583^{*}(0.004)$ \\
\hline
\end{tabular}

*1 per cent level of significance. Figures in the parentheses denote standard errors of their respective coefficients.

Table 4. Growth trend of area, production and yield in major maize growing districts of Jammu region from 1987-88 to 2006-07

\begin{tabular}{lccc}
\hline Districts & Area & Production & Yield \\
\hline Jammu & $1.469^{*}(0.006)$ & $2.047^{*}(0.006)$ & $0.792^{*}(0.002)$ \\
Kathua & $0.275^{*}(0.004)$ & $0.887^{*}(0.008)$ & $1.558^{*}(0.004)$ \\
Udhampur & $1.371^{*}(0.022)$ & $-0.422^{*}(0.005)$ & $-1.462^{*}(0.005)$ \\
Doda & $0.685^{*}(0.001)$ & $-3.637^{*}(0.099)$ & $-4.021^{*}(0.019)$ \\
Rajouri & $0.630^{*}(0.001)$ & $1.032^{*}(0.005)$ & $0.493^{*}(0.005)$ \\
Poonch & $0.363^{*}(0.001)$ & $-0.727^{*}(0.005)$ & $-0.606^{*}(0.005)$ \\
Jammu Region (maize growing districts) & $0.800^{*}(0.001)$ & $0.351^{*}(0.003)$ & $-0.583^{*}(0.003)$ \\
\hline
\end{tabular}

*1 per cent level of significance. Figures in the parentheses denote standard errors of their respective coefficients

million tonnes and 4.225 million tonnes with respect to area and yield, respectively. These results were similar to those of the findings revealed by Singh et al. (2003) while studying transformation of the Indian maize economy. The above discussion clearly shows that during the period I yield of maize showed the better performance in production of maize as compared to change in area but during period II, the area under maize crop had increased production more as compared to the change in yield. However, the overall effect of two periods on production, yield was found to contribute more towards production growth as compared to change in area under maize crop, which attributed to either advancement in technology or higher inputs use. Table 6 indicated that the yield remained the major contributor to the production during period I (0.014 million tonnes) and period II (0.027 million tonnes) as compared to area 0.012 million tonnes and 0.014 million tonnes, respectively for the state of Jammu and Kashmir. The interaction effect of change in area and yield was higher for period II (0.009 million tonnes) as compared to period I ( 0.005 million tonnes). These findings were supported by Anupama et al. (2005) for studying technical efficiency in maize production in M.P and Chahal and Kataria (2003) for studying maize production in Rajasthan but with higher values. In short the yield of maize improved in the state during both the periods but its benefits could not be sustained due to slight increase in area. It might be due to the less availability of quality seeds, fertilizers, pesticides, credit etc. Though the state has provision for the above mentioned inputs but those do not reach the real growers due to lack of extension workers.

As far as Jammu region was concerned, area contributed almost equally and positively in production during the period I (0.018 million tonnes) and period II (0.017 million tonnes) as shown in Table 7 , while negative yield effect was recorded during period I (-0.030 million tonnes) and overall period (-0.026 million tonnes), while yield played the significant role in the increase in maize production during the second period. The interaction effect of area and yield had reduced production by (-) 0.001 million tonnes during period I, while as during period II, change in area, yield and interaction effect had a positive effect on production i.e., 0.017 million tonnes, 0.004 million tonnes and 0.001 million tonnes, respectively. For the overall period the area effect was 0.056 million tonnes on production, area and yield interactive effect had decreased production by (-) 0.004 million tonnes. These findings were supported by Chahal and Kataria (2003) for studying maize production in Rajasthan. Thus, it may be attributed to change in area, which had affected maize production positively in Jammu region of J\&K State and change in yield had negatively affected production because in the traditional maize growing areas, most farmers still grow local maize varieties during the rainy season and seed replacement is very low.

Area effect, yield effect and their interaction effect on the change in production of maize crop (Table 8) showed that area positively contributed to the maize production in selected districts (Doda and Udhampur) during all the periods. It was 0.008 million tonnes and 0.001 million tonnes in period I, 0.004 million tonnes and 0.012 million tonnes in period II and 0.010 million tonnes and 0.027 million tonnes during the overall period for Doda and Udhampur districts, respectively. The contribution of yield effect and interaction effect to the maize production dropped considerably and reduced production in Doda district by (-) 0.013 million tonnes and (-) 0.001 million tonnes during period I and (-) 0.024 million tonnes and (-) 0.001 million tonnes in period II and in Udhampur district also, the yield effect was negative and reduced production by (-) 0.016 million tonnes during period II but positive for period I (0.009 million tonnes). Whereas the interaction effect of area and yield was positive for the period I, II and negative for overall period as similarly studied by Verghese and Rathore (2003) for maize production in 
Table 5. Growth trend of area, production and yield of maize crop in sample districts

\begin{tabular}{lllll}
\hline S.N. & Particulars & Period I (1987-88 to1996-97) & Period II (1997-98 to 2006-07) & Overall period (1987-88 to 2006-07) \\
\hline & & & Doda & \\
\hline 1 & Area & $1.247^{*}(0.001)$ & $0.587 *(0.001)$ & $0.685^{*}(0.001)$ \\
2 & Production & $(-) 0.360 *(0.01)$ & $(-) 1.007 *(0.038)$ & $(-) 3.637 *(0.099)$ \\
3 & Yield & $(-) 0.684 *(0.01)$ & $(-) 1.586^{*}(0.038)$ & $(-) 4.021 *(0.019)$ \\
\hline & & & Udhampur & $1.371 *(0.022)$ \\
\hline 1 & Area & $(-) 0.204 *(0.004)$ & $0.674 *(0.004)$ & $(-) 0.422 *(0.005)$ \\
2 & Production & $0.179 *(0.011)$ & $(-) 3.441 *(0.016)$ & $(-) 1.462 *(0.005)$ \\
3 & Yield & $1.435 *(0.008)$ & $(-) 4.087 *(0.014)$ & \\
\hline
\end{tabular}

* 1 per cent level of significance. Figures in the parentheses denote standard errors of their respective coefficients

Table 6. Effect of change in area, yield and interaction of differential production of maize crop in India (Million tonnes)

\begin{tabular}{llll}
\hline Particulars & Area effect $\mathbf{Y}_{\mathbf{0}} \Delta \mathbf{A}$ & Yield effect $\mathbf{A}_{\mathbf{0}} \Delta \mathbf{Y}$ & Interaction effect $\Delta \mathbf{A} \Delta \mathbf{Y}$ \\
\hline 1987-88 to 1996-97 & 0.714 & 3.892 & 2.778 \\
1997-98 to 2006-07 & 2.470 & 0.442 & 1.091 \\
Overall Total 1987-88 to 2006-07 & 2.225 & 4.225 & 9.40 \\
\hline
\end{tabular}

Table 7. Effect of change in area, yield and interaction of differential production of maize crop in Jammu and Kashmir state (Million tonnes).

\begin{tabular}{llll}
\hline Particulars & Area effect $\mathbf{Y}_{\mathbf{0}} \Delta \mathbf{A}$ & Yield effect $\mathbf{A}_{\mathbf{0}} \Delta \mathbf{Y}$ & Interaction effect $\Delta \mathbf{A} \Delta \mathbf{Y}$ \\
\hline 1987-88 to 1996-97 & 0.012 & 0.014 & 0.005 \\
1997-98 to 2006-07 & 0.014 & 0.027 & 0.009 \\
Overall Total 1987-88 to 2006-07 & 0.303 & 0.142 & 0.014 \\
\hline
\end{tabular}

Rajasthan. The reasons for negative effect on yield was that the most of the kharif maize is cultivated in rainfed conditions and maize cultivation operations were performed traditionally mode with less number of irrigations, most of the farmers were growing other crops like paddy and vegetables under the irrigated conditions. Further, yield decreased largely because the farmers increasingly cultivated traditional cultivars and did not make the use of inorganic fertilizers, pesticides and other chemicals which are used for the control of weed. They lacked technical and scientific know-how and were facing the problems like non-availability of hybrid seeds and fertilizers at the reasonable rates. Weeding and other crop care/ management practices which are considered to be the most important factors affecting any crop production were lacking in the sample area.

Resource-use efficiency: Efficiency is an important factor in productivity growth. In an economy where resources are scarce and opportunities for new technologies are lacking, inefficiency studies will be able to show that it is possible to raise productivity by improving efficiency without increasing the resource base or developing new technology. Estimates of the extent of inefficiency also help in deciding whether to improve efficiency or to develop new technologies to raise agricultural productivity. It is recognized fact that functional analysis of the relationship between output and input factors serves as a powerful and reliable tool for resource allocation in the cultivation of the crop at the farm level. The regression co-efficient of factor input from Cobb-Douglas production function (OLS) were used to calculate the Marginal Value Productivity (MVP) at Geometric Mean level for the average farms.
The estimates of Cobb-Douglas production function (OLS) are given in Table 9. Yield of maize was regressed on various factors of production viz, labour, capital, irrigation and fertilizers $(\mathrm{N}, \mathrm{P}$ and $\mathrm{K})$. These variables were taken as the explanatory variables. Ordinary least square estimates of Cobb-Douglas production function showed (Table 9) the co-efficient of multiple determinations $\left(\mathrm{R}^{2}\right)$ indicated that 44 per cent of the variation in the yield could be explained by the variables considered in the model for the maize crop. Similar findings were observed by Anupama et al. (2005) for studying technical efficiency in maize production in M.P. The average performance of the sample farmers and the estimated coefficient of labour was positive $(0.338)$ and statistically significant at one per cent level of significance, which indicated that maize yield could be increased 0.338 per cent by using more human labour, while keeping other factors constant. These results are in consistency with the findings of Hasan (2008) and Mohiuddin et al. (2007) for studying economic efficiency and constraints of maize production in the northern region of Bangladesh. The statistical significance (at 1 per cent level of significance) for the regression coefficient of capital implied that 0.306 per cent production could be increased with one per cent increase in capital used. Similar findings were observed by Anupama et al. (2005). The results further indicated that the coefficients of $\mathrm{N}(0.324)$ and $\mathrm{K}(0.202)$ were positive and significant at one per cent level of significance, indicating there by that maize yield could be increased by 0.324 and 0.202 per cent by employing more units of these inputs. It is in conformity with the findings of Hasan (2008) for studying economic efficiency and 
Table 8. Effect of change in area, yield and interaction of differential production of maize crop in Jammu region of J\&K state (Million tonnes)

\begin{tabular}{llll}
\hline Particulars Effect & Area effect $\mathbf{Y}_{\mathbf{0}} \Delta \mathbf{A}$ & Yield effect $\mathbf{A}_{\mathbf{0}} \Delta \mathbf{Y}$ & Interaction effect $\Delta \mathbf{A} \Delta \mathbf{Y}$ \\
\hline 1987-88 to 1996-97 & 0.018 & $(-) 0.030$ & $(-) 0.001$ \\
1997-98 to 2006-07 & 0.017 & 0.004 & 0.001 \\
Overall Total 1987-88 to 2006-07 & 0.056 & $(-) 0.026$ & $(-) 0.004$ \\
\hline
\end{tabular}

Table 9. Effect of change in area, yield and interaction of differential production of maize in selected districts (Million tonnes).

\begin{tabular}{llll}
\hline Particulars & Area effect $\mathbf{Y}_{\mathbf{0}} \Delta \mathbf{A}$ & \multicolumn{1}{c}{ Yield effect $\mathbf{A}_{\mathbf{0}} \Delta \mathbf{Y}$} & Interaction effect $\Delta \mathbf{A} \Delta \mathbf{Y}$ \\
\hline & \multicolumn{4}{c}{ Doda } \\
\hline 1987-88 to 1996-97 & 0.008 & $(-) 0.013$ & $(-) 0.001$ \\
1997-98 to 2006-07 & 0.004 & $(-) 0.024$ & $(-) 0.001$ \\
Overall Total 1987-88 to 2006-07 & 0.010 & $(-) 0.010$ & $(-) 0.021$ \\
\hline & 0.001 & Udhampur & 0.002 \\
\hline 1987-88 to 1996-97 & 0.012 & 0.009 & 0.002 \\
1997-98 to 2006-07 & $(-) 0.016$ & $(-) 0.007$ \\
Overall Total 1987-88 to 2006-07 & 0.027 & $(-) 0.024$ &
\end{tabular}

constraints of maize production in the northern region of Bangladesh and Oluwatayo et al. (2008) for studying resource use efficiency of maize farmers in rural Nigeria. Phosphorus (P) with statistically significant negative value (-) 0.097 revealed the excessive use of $\mathrm{P}$ and if $\mathrm{P}$ was increased furthermore, it could rather reduce the maize production by 0.097 per cent. Chowdhury (1992) found a negative and insignificant coefficient for fertilizer in maize production. In the case of irrigation, the co-efficient were positive $(0.043)$ but statistically non- significant. This implied that irrigation had not much more role to play in the production of maize crop in the study area.

Allocative efficiency of sample farms: Further, for estimating the marginal conditions for profit maximization, allocative efficiency was computed. To attain the goal of profit maximization i.e., for efficient resources allocation, more use of the resources as long as the value of the added product is greater than cost of the added amount of the resources in producing it. The resources are to be considered efficiently used and profit will be maximum, when the marginal value product (MVP) and marginal factor cost (MFC) for each input is equal. The MVP of a particular resource represents the addition to gross return in value terms caused by an addition of one unit of that resource while other inputs are held constant. The estimated MVP, MFC and allocative efficiency (ratio of MVP to MFC) of different inputs in study area are presented in Table 10 .

The MVP of various inputs namely labour, capital, irrigation and fertilizers $(\mathrm{N}, \mathrm{P}, \mathrm{K})$ were worked out at their geometric mean level in order to compare the estimates of allocative efficiency and their productivity. The estimated MVP and MFC ratio i.e. allocative efficiency of different inputs in the study area could be seen from Table 10. In case of irrigation and fertilizers $(\mathrm{N}, \mathrm{K})$ the ratio of MVP and MFC were greater than one and positive, which indicated the increasing returns to scale. Therefore, it means that the maize farmers were utilizing these resources sub-optimally and if amount of these resources were increased, they could increase the output more than proportionally, which is in conformity to the findings of Duloy (1959) and Hasan (2008). In case of capital and human labour used, though their contribution to maize output was positive which was clear from their positive regression coefficient, but was less than one, indicating thereby diminishing returns to scale which meant that one per cent increase in these inputs could increase the maize output less than one per cent or the total output could increase at a decreasing rate. The ratio of fertilizer $(\mathrm{P})$ was negative but greater than one hence, this input for maize production was not used efficiently in sample farms, which lead to the reduction of yield. These findings were supported by Mohiuddin et al. (2007) for studying efficiency and sustainability of maize cultivation in an area of Bangladesh.

Technical efficiency of sample farms: Estimation of the efficiency level helps to decide whether to improve the existing efficiency level or to develop new technologies to raise the productivity level. A farm is technically inefficient in the sense that if it fails to produce maximum output from a given level of input i.e., it results into equi- proportionate, over or under utilization of all inputs. Using maximum likelihood estimation techniques, the Stochastic Production Frontier was employed to estimate technical efficiency at farm level in the study area. The dependent variable included in the model was the output of maize crop and the independent variables were labour, capital, fertilizers (N, P and $\mathrm{K}$ ) and irrigation. The estimates of frontier production function for the maize crop were given in 11. The estimates of stochastic frontier showed the best practice i.e., efficient use of available technology. The information from Table 11 indicated that the dependent variable included in the model was output of maize crop. The independent variables included human labour, capital, fertilizers (N, P, K) and irrigation. The regression coefficient of labour, capital, and fertilizers $(\mathrm{N}, \mathrm{K})$ were positive and significant at one per cent level of significance, indicating 0.378 per 
Table 10. Estimated values of the coefficients and related statistics of Cobb-Douglas production function model.

\begin{tabular}{lll}
\hline Explanatory variables & Coefficients & Standard error \\
\hline Constant & $(-) 1.050$ & 0.263 \\
Labour (L) & $0.338^{*}$ & 0.111 \\
Capital (K) & $0.306^{*}$ & 0.115 \\
Irrigation (I) & 0.043 & 0.041 \\
Fertilizers (F) & & \\
N & $0.324^{*}$ & 0.063 \\
P & $(-) 0.097^{* *}$ & 0.046 \\
K & $0.202^{*}$ & 0.041 \\
$\mathrm{R}^{2}$ & & \\
\hline
\end{tabular}

*Significant at $1 \%$ level of probability, ** Significant at $5 \%$ level of probability

Table 11. Allocative efficiency of sample farms.

\begin{tabular}{lllll}
\hline Explanatory variables & Coefficients & MVP & MFC & Allocative efficiency \\
\hline Constant & $(-) 1.050$ & 1.077 & 76.766 & 0.014 \\
Labour (L) & 0.338 & 5.242 & 7.846 & 0.668 \\
Capital (K) & 0.306 & 9.045 & 8.871 & 1.019 \\
Irrigation (I) & 0.043 & & & \\
Fertilizers (F) & & 16.221 & 5.000 & 3.244 \\
N & 0.324 & $(-) 12.055$ & 6.958 & $(-) 1.732$ \\
P & $(-) 0.097$ & 48.510 & 3.625 & 13.380 \\
K & 0.202 & & \\
\hline
\end{tabular}

cent, 0.336 per cent, 0.244 per cent and 0.292 per cent increase in maize production with one percent increase in these inputs. The value of regression coefficient of irrigation was positive but insignificant. The positive sign implies that one per cent increase in irrigation, keeping other factors constant, could increase the yield by 0.225 per cent and the regression coefficient of fertilizer $(\mathrm{P})$ was negative and insignificant, the negative algebraic sign and statistical insignificance for coefficient Phosphorus was due to its over use. The estimated value of $\lambda$ was 4.219 and $\sigma$ was 0.455 , which were significantly different from zero indicating a good fit and the correctness of the distributional assumptions specified. The value of $\lambda$ was more than one, employing the dominance of one sided component $\mathrm{U}_{\mathrm{i}}$ in $\mathrm{E}_{\mathrm{i}}$ and thus indicated high degree of technical inefficiency. In other words the inefficiency component was not dominated by the random factors. The variance ratio $\gamma$ showed that the farm specific variability contributed more to the variation in yield, which means that variation in output from frontier is attributed to technical inefficiency. The value of $\gamma$ was 0.946 meaning thereby that about 94 percent of the differences between the observed and the maximum production frontier outputs were due to the factors, which were under farmers' control. The stochastic frontier analysis further showed that 94 per cent of the observed inefficiency was due to farmers' inefficiency in decision making and only 6 percent of it was due to random factors outside their control. These results are in conformity with Shanmugam and Venkataramani (2006) for studying technical efficiency in agricultural production and its determinants and Ogundari, (2006) for studying resource productivity, allocative efficiency and determinants of technical efficiency of rainfed rice farmers.

The estimated value of $\sigma^{2}{ }_{v}$ and $\sigma^{2} u$ were 0.011 and 0.196 respectively, which means that the differences between the observed and frontier output were due to inefficiency and not due to chance alone. Since the frontier parameters indicated the maximum possible contribution of each input to output, when the inputs are utilized efficiently with the help of best farming techniques.

The results on elasticity of production and return to scale could be seen from the Table 12. The regression coefficients in the frontier production function are the production elasticities, and their sum indicates the returns to scale. All of the individual elasticities of production were less than one, but the summation of elasticities of different inputs were greater than one $(1.092>1)$ indicating increasing returns to scale. This indicated that farmers in general, allocated their resources in the irrational zone of production (stage 1) where the increasing returns to scale prevails, that is, if all the inputs specified in the function were increased by one per cent, output would have increased by 1.092 per cent, which also means that there is the area potentiality of increasing maize production further till the completion of second stage of production (as among the three stages of "law of variable proportions" second stage of production function is rational zone of production) These results are in conformity with the findings of Dolisca and Jolly (2008), Adeleke et al. (2008) for studying application of Stochastic Frontier in the estimation of technical efficiency of Cassava farmers in Oluyole and Akinyele local government areas of Oyo State and Mohiuddin et al. (2007) for studying efficiency and sustainability of maize cultivation in an area of Bangladesh. Labour appeared to be the most 
important factor of production with highest elasticity of 0.378 , among all other factors showing the labourintensive nature of farming in the study area. Statistically significant elasticity suggested that 1 percent increase in labour would result in an increase of 0.378 percent in production of maize crop. These results are in agreement with the work reported by Amaza and Olayemi (2000) for studying technical efficiency in food crop production in Gambe State, Nigeria.

Factors affecting technical efficiency: The measure of technical efficiency of a farmer indicated that if any farmer is successful in converting all the physical units into output and efficiency of converting is equal to the hypothetical frontier production function, then it is said to be an efficient farmer and if any farmer falls short of this requirement then the farmer is termed as technically inefficient farmer. The technical efficiency of many farmers is determined by various factors like age of the head, education, size of farm and proportion of female workers in the family and the same has been presented in Table 13. The multiple regression results concluded that there is interaction between the level of farm efficiency and socio-economic variables. Interpretation of results yields a number of additional insights into the process of factors affecting technical efficiency among maize growers in Jammu region of J\&K State. The coefficient for constant is positive and highly significant, thereby indicated that per hectare production was high with the given mean quantities of inputs. The dummy variable for age was negative $(-0.001)$ and insignificant, suggesting that younger farmers, who were less than 50 years, were more efficient than the older ones. This means that the aged farmers were not adopting the new technology for maize crop production in the study area. These results are consistent with the findings of Bravo-Ureta and Evenson (1994) and Abdulai and Eberlin (2001) for studying technical efficiency during economic reform in Nicaragua. Hussain (1989) while studying analysis of economic efficiency in Northern Pakistan observed that older farmers are less likely to have contacts with extension workers and are less willing to adopt new practices and modern inputs. The reason for this is probably because the age variable picks up the effects of physical strength as well as farming experience of the household head. Although farmers become more skillful as they grow older, the learning by doing effect is attenuated as they approach middle age, as their physical strength starts to decline. Similar conclusions were made by Abdulai and Huffman (2000) while studying structure adjustment and economic efficiency of rice farmers in Northern Ghana. The variable education (0.023) was positive and significant at 1 per cent level of probability, had positive impacts on the technical efficiency level for maize farmers. This implies that farmers with better education were technically more efficient. These finding are similar to Dey et al. (2000), who found that farm efficiency increases with level of education. Increased level of educational achievement may lead to a better evaluation of the importance of better farming, decision making, including the efficient use of inputs. A good level of education enhances a farmer's ability to seek, interpret and make good use of information and production inputs. A study by Seyoum et al. (2000) on technical efficiency and productivity of maize producers in Eastern Ethiopia concluded that farmers with more education respond more readily to new technology and produce closer to the frontier output. This finding is also consistent with results on structural adjustment and economic efficiency of rice farmers in Northern Ghana by Abdulai and Huffman (2000). From these results, it can be concluded that a maize producer need education to know the correct amount of fertilizer to be applied, correct seed rate and general management of the farm. The positive and statistically significant coefficients for the proportion of female workers under study indicated that females were contributing a lot in the various operations of maize cultivation e.g, in harvesting, storing of produce, weeding etc, their participation was more than their male counterparts. The reason for that their male members mostly migrated to other places in search of other jobs either as labourers or as employees. Thus, it could be seen that female workers had better opportunities to carry out frequent follow-up and supervision of the farm activities on their plots. This is consistent with the findings of Onyenweaku and Effiong, (2005) and Dolisca and Jolly (2008). The variable for the proportion of children in the family was positive, but statistically insignificant. Thus indicated that children had nothing to do with efficiency i.e.,

Table 12. Results of maximum likelihood estimation for frontier production function.

\begin{tabular}{llll}
\hline Variables & $\begin{array}{l}\text { Frontier production } \\
\text { function estimates (MLE) }\end{array}$ & Standard error & $\begin{array}{l}\text { Variance } \\
\text { Parameters }\end{array}$ \\
\hline Constant & $(-) 0.709$ & 0.243 & $\sigma^{2}{ }_{\mathrm{u}=0.196}$ \\
Labour (L) & $0.378^{*}$ & 0.081 & $\sigma^{2}=0.011$ \\
Capital (K) & $0.336^{*}$ & 0.116 & $\sigma=0.455$ \\
Irrigation (I) & 0.225 & 0.380 & $\lambda=4.219$ \\
\hline Fertilizers (F) & & & $\gamma=0.946$ \\
$\mathrm{~N}$ & $0.244^{*}$ & 0.059 & Likelihood=-24.183 \\
$\mathrm{P}$ & $(-) 0.383$ & 0.042 & \\
$\mathrm{~K}$ & $0.292^{*}$ & 0.033 & \\
\hline
\end{tabular}

*Significant at $1 \%$ level of probability 
Table 13. Elasticity of production of different inputs and their return to scale.

\begin{tabular}{ll}
\hline Variable & Elasticity \\
Labour (L) & 0.378 \\
Capital (K) & 0.336 \\
Irrigation (I) & 0.225 \\
\hline Fertilizers (F) & \\
\hline N & 0.244 \\
P & $(-) 0.383$ \\
K & 0.292 \\
RTS & 1.092 \\
\hline
\end{tabular}

they were neither technically efficient nor inefficient. The farm size showed a significant and positive relationship with regard to technical efficiency, which means that the farm size had a major influence on the efficiency of sample farm. Similar conclusions were made by Kumar et al. (2005).

\section{Conclusion}

It was concluded among the different variables under study human labour, capital and fertilizers ( $\mathrm{N}$ and $\mathrm{K}$ ) were positively significant and could increase the yield by employing more units of these inputs in producing the maize crop in selected districts and value of $\gamma$ was 0.94 , indicated that about 94 percent of the differences between the observed and the maximum production frontier outputs were due to the factors, which were under farmers' control rather than random factors. This study provides the evidence that age of the farmer, education, female workers and the size of holding were the significant variables for improving technical efficiency among the sample farmers, where as the male workers and children in the family showed the negative relationship with technical efficiency under the study area.

The maize scenario in future has to be seen in the light of competitiveness from other crops and measures have to be taken up to keep it profitable. The districts having low yield have to be focused strongly to improve the yield. High costs involved inputs mainly, quality maize seeds, fertilizers, pesticides and micronutrients needs attention. Hence, financial assistance has to be given to farmers to purchase inputs. Furthermore, a government agency may be set up to procure the crop produce or any other institutional arrangement like contract farming may be initiated to assure the farmers about the marketability of their produce. The technical efficiency indicated that there was about $48 \%$ potential for increasing the gross income of the farmers with existing levels of farmers' resources and technology. This will help to increase not only the national pool of maize production but also increase the farm income of the maize growers considerably.

\section{REFERENCES}

Abdulai, A. and Eberlin R. (2001). Technical efficiency during economic reform in Nicaragua: Evidence from farm household survey data. Economic System, 25 (2): 113-125.
Table 14. Determinants of technical efficiency in maize production.

\begin{tabular}{llc}
\hline Variable & Coefficient & Standard error \\
\hline Constant & 0.164 & 0.141 \\
Age & $(-) 0.001$ & 0.002 \\
Education & $0.023^{*}$ & 0.011 \\
Female workers & $0.062^{* *}$ & 0.034 \\
Children & 0.036 & 0.040 \\
Farm size & $0.878^{*}$ & 0.004 \\
\hline
\end{tabular}

*Significant at $1 \%$ level of probability; ** Significant at $5 \%$ level of probability.

Abdulai, A. and Huffman W. (2000). Structure adjustment and economic efficiency of rice farmers in Northern Ghana. Economic Development and Cultural Change, 503-519.

Adeleke, O.A., Fabiyi Y.L. and. Matanmi H.M. (2008). Application of stochastic frontier in the estimation of technical efficiency of cassava farmers in Oluyole and Akinyele local government areas of Oyo State. Research Journal of Agronomy, 2(3): 71-77.

Aigner, D.J., Lowell C.A.K. and Schmidt P. (1977). Formulation and estimation of stochastic frontier production function models. Journal of Economics, 6 (1): 21-37.

Amaza P. S. and. Olayemi J. K (2000). Technical efficiency in food crop production in Gambe State, Nigeria. Niger Agricultural Journal, 32: 140-151.

Anonymous, (2008). Directorate of Economics and Statistics, Planning and Development Department, Govt. of Jammu and Kashmir.

Anupama, J. Singh R.P. and Kumar R. (2005). Technical efficiency in maize production in M.P”. Agricultural Economics Research Review, 18: 305-315.

Awasthi, P.K. (2003). Maize production in Madhya Pradesh: A district level analysis. In : Maize Production in IndiaGolden Grain in Transition (Eds. Kumar, R. and Singh, N.P.). Technical bulletin TB- ICN: 4/2003, Division of Agricultural Economics, Indian Agricultural Research Institute, New Delhi, pp. 60-76.

Bravo-Ureta, B.E. and Evenson, R.E. (1994). Efficiency in agricultural production: the case of peasant farmers in eastern Paraguay. Agricultural Economics, 10(1): 27 37.

Chahal, S.S. and Kataria P. (2003). Maize production in Rajasthan: A district level analysis. In : Maize Production in India- Golden Grain in Transition (Eds. Kumar, R. and Singh, N.P.)". Technical bulletin TB- ICN: 4/2003, Division of Agricultural Economics, Indian Agricultural Research Institute, New Delhi, pp. 88-105.

Chowdhury, J.M. (1992). Study on production potential and economic evaluation of maize based cropping systems under mid-hill conditions of Himachal Pradesh. Farming Systems, 8(3/4): 70-78.

Dey, M. M., Paraguas, F.J., Bimbao, G.B. and Regaspi, P.B. (2000). Technical efficiency of tilapia grows out pond operations in the Philippines. Aquacultural Economic Management, 4(1-2): 33-47.

Dolisca, F. and. Jolly, C.M. (2008). Technical efficiency of traditional and non-traditional crop production: A Case Study from Haiti. World Journal of Agricultural Sciences, 4(4): 416-426.

Duloy, J.H. (1959). Resource allocation and fitted production 
function. Australian Journal of Agricultural Economics, 3(2): 33-39.

Hasan, F.M. (2008). Economic efficiency and constraints of maize production in the northern region of Bangladesh. Journal of Innovative Development Strategy, 2(1):1832.

Hussain, S.S. (1989). Analysis of economic efficiency in northern Pakistan: Estimation, causes and policy implications. Ph.D. Dissertation, University of Illinois.

Kachroo, J. and Kachroo, D. (2006). Growth, instability and projection of silk production in Jammu and Kashmir State. Journal of Research, SKUAST-Jammu, 5(1): 2034.

Kachroo, J. and Sharma, M. (2008). Sunflower scenario in India. Journal of Research, SKUAST-Jammu, 7(1): 122131.

Kumar, L.R., Srinivas, K. and Singh, S.R.K. (2005). Technical efficiency of rice farms under irrigated conditions of North West Himalayan region- a non-parametric approach. Indian journal of agricultural economics, 60 (3): 483-492.

Meeusen, W. and Van Den Broeck, J. (1977). Efficiency estimation from Cobb-Douglas production functions with composed errors. International Economic Review, 18(3): 163-173.

Mohiuddin, M., Karim, M.R., Rashid, M.H. and Hudda, M.S. (2007). Efficiency and sustainability of maize cultivation in an area of Bangladesh. Int. J. Sustain. Crop Production, 2(3):44-52.

Ogundari, K. (2006). Resource-productivity, allocative efficiency and determinants of technical efficiency of rainfed rice farmers: A guide for food security policy in Nigeria. Journal of Sustainable Development in Agriculture \& Environment, 3(2):20-33.
Oluwatayo, I.B. Sekumade, A.B. and Adesoji, S.A. (2008). Resource use efficiency of maize farmers in rural Nigeria: Evidences from Ekiti State. World Journal of Agricultural Sciences, 4(1): 91-99.

Onyenweaku C.E., and Effiong, E.O. (2005). Technical efficiency in pig production in Akwalbom State, Nigeria. International Journal of Agricultural Rural Development, 6:51-57.

Seyoum, E.T.. Battese G.E, and Fleming, E.M. (2000). Technical efficiency and productivity of maize producers in Eastern Ethiopia: A study of farmers within and outside the Sawakawa-Global 2000 Project. Agricultural Economics, 19:341-348.

Shanmugam, K.R. and Venkataramani, A. (2006). Technical efficiency in agricultural production and its determinants. An exploratory study at district level. Indian journal of agricultural Economics, 16(2): 169-184.

Singh, R.P., Kumar, R. and Singh, N.P. (2003). Transformation of the Indian maize economy - different perspectives. In:Maize Production in India-Golden Grain in Transition (Eds. Kumar, R. and Singh, N.P.). Technical bulletin TB- ICN: 4/2003, Division of Agricultural Economics, Indian Agricultural Research Institute, New Delhi, pp. 1-28.

Verghese, K.A. and Rathore R.S. (2003). Maize production in Rajasthan: A district level analysis. In : Maize Production in India- Golden Grain in Transition (Eds. Kumar, R. and Singh, N.P.). Technical bulletin TBICN: 4/2003, Division of Agricultural Economics, Indian Agricultural Research Institute, New Delhi, pp. 106-120.

Yotopoulos, P.A. (1967). Allocative Efficiency in Economic Development, Research Monograph Series, No. 18 (191 -192), Constantinidis and C. Mihalas, Athens. 